\title{
An Interpretative Survey of Oil Price-GDP Elasticities
}

\author{
F. Lescaroux \\ Institut français du pétrole, IFP, 1 et 4 avenue de Bois-Préau, 92852 Rueil-Malmaison - France \\ e-mail: francois.lescaroux@ifp.fr
}

Résumé - L'élasticité entre le prix du pétrole et le PIB : revue et interprétation des résultats Dans le contexte de la hausse des prix observée depuis cinq ans, l'objectif de cette note est d'apporter quelques lumières sur les conséquences possibles du renchérissement du baril. Nous commencerons par présenter brièvement les principaux résultats des analyses réalisées, depuis trente ans, quant à l'influence du prix de l'énergie sur l'activité économique. Nous interpréterons ensuite ces études et leurs conclusions dans un cadre fréquentiel en distinguant les effets d'un déséquilibre à la hausse et d'une hausse de l'équilibre dans la chronique du prix du pétrole. Nous tenterons d'en tirer des enseignements concernant les effets à attendre de l'évolution récente des marchés énergétiques.

Abstract - An Interpretative Survey of Oil Price-GDP Elasticities - In the context of rising crude oil prices observed in the last five years, this paper attempts to shed light on the possible consequences of a costlier barrel. We shall begin with a brief presentation of the main results of the analyses conducted in the last 30 years, concerning the impact of energy prices on economic activity. We shall then interpret these analyses and their conclusions in a frequencies framework by distinguishing between the impact of an upward disequilibrium and an upturn in the equilibrium of the oil prices. We shall try to draw a number of lessons about the anticipated effects of the recent trend in energy prices. 


\section{INTRODUCTION}

The question of the macroeconomic impact of oil price movements comprises a significant political component, and all sorts of opinions have currency. Some of them, held by a small minority, claim that the price increases are in fact favourable to growth [1] while others find in the same increases premonitory signs of the apocalypse, or at least of a recession. From the quantitative standpoint, the estimates of the impact of an oil price variation on macroeconomic activity fail to agree. As to the United States, for example, elasticities between real GDP (Gross Domestic Product) and oil price (i.e. the ratio of the rate of change of real GDP to the rate of change of the oil price) evaluated using econometric models, form a wide spectrum, stretching from a value close to $-1 \%$ for the OECD/IEA (Organisation for Economic Co-operation and Development/International Energy Agency, [2]) to $-11.62 \%$ for James D. Hamilton [3]. Thus from one extreme to the other, a $\$ 10$ rise in the price per barrel, from $\$ 20$ to $\$ 30$, causes an American GDP deviation ranging between about $0.5 \%$ to over $5.5 \%$, from the reference level.

The differences between empirical estimates reflect a temporal instability of the relationship, as well as theoretical disagreements about the mechanism by which a fluctuation in the crude price propagates through the economic system and affects the economic situation.

\section{THE INFLUENCE OF OIL PRICE VARIATIONS: THEORY AND EMPIRICAL RESULTS}

Studies conducted immediately after the first oil shock explained a set of "standard" effects that enjoy a relative consensus. The first sub-section will explain how oil price variations affect an economic system. The second one will distinguish between the effects of short-run oil price variations and the effects of "oil price shocks". Thirdly, the results of some disaggregated analyses will be presented. Lastly, the main sources of instability in the analyses performed will be listed.

\subsection{Static Macroeconomic Analysis}

For any economy, an oil price increase represents an exogenous inflationary shock.

International trade is affected thereby, because the rising price of one of its most widely traded commodities upsets the terms of trade between the net exporting and importing countries. Through a price effect, the latter first suffer a deterioration of their trade balances; over the longer term, exchange rate adjustments and demand of the exporting countries for goods, services and savings, determine subsequent developments.

In terms of national economies, a rise in the price of crude oil is passed on to the price of petroleum products and, from the consumer standpoint, the energy bill of the agents (households, industry and government) grows, whereas from the production standpoint, companies have to contend with a rise in unit costs. As to demand, this slows down consumption expenditures, unless the price change is perceived as shortlived and the agents prefer to maintain their standard of living by reducing their savings or by borrowing (which would exert upward pressure on interest rates). In terms of supply of goods and services, a rise in the energy price causes a drop in productivity, which is passed on to:

- real wages and employment;

- selling prices and core inflation;

- profits and investment, as well as stock market capitalization.

The theoretical analysis of the mechanisms whereby an oil price increase propagates through the economic system is based on a "decision tree" type of structure: depending on the decisions made by the economic agents, the detriment caused by a costlier barrel is supported in variable proportions by the various types of players (employees, entrepreneurs, shareholders, consumers, investors, etc.). Figure 1 shows the initial chaining of some of the possible trajectories.

Regardless of the decisions made, real economic growth will be smaller than what it would have been in the absence of an oil price increase. On the other hand, the impact on the other macroeconomic indicators, particularly on value added distribution and real interest rates, is ambiguous and conditioned by the way in which the price increase propagates through the economic system (Fig. 1).

However, the inclusion of these effects in standard econometric models - systems of structural equations or compact models of the VAR (Vector Auto-Regression) family - has rapidly revealed that the impact of the crude oil price on economic activity is exerted in an unstable manner, both in the short term and over a long period. As to this second form of instability, the statistical equations estimated until the end of the 1970s appear to weaken from the onset of the 1980s, until they become non-significant during the 1990s [4, 5].

This finding has led to various interpretations. Economists who worked on the subject have suggested many explanations, sometimes complementary, often contradictory.

Some of them have tried to understand why we observed this progressive attenuation and short term variability of the effects of the oil price movements.

Others, on the contrary, have interpreted the insufficient quality of the estimated equations as the sign that the impact of the oil price had hitherto been improperly construed. They have accordingly attempted to identify the consequences specific to the sudden and striking changes in prices, which would legitimize a nonlinear influence on the aggregate indicators of economic activity, and they try to identify stable relations between "oil shock" measurements, expressing such effects, and the variations in GDP or unemployment rate. 


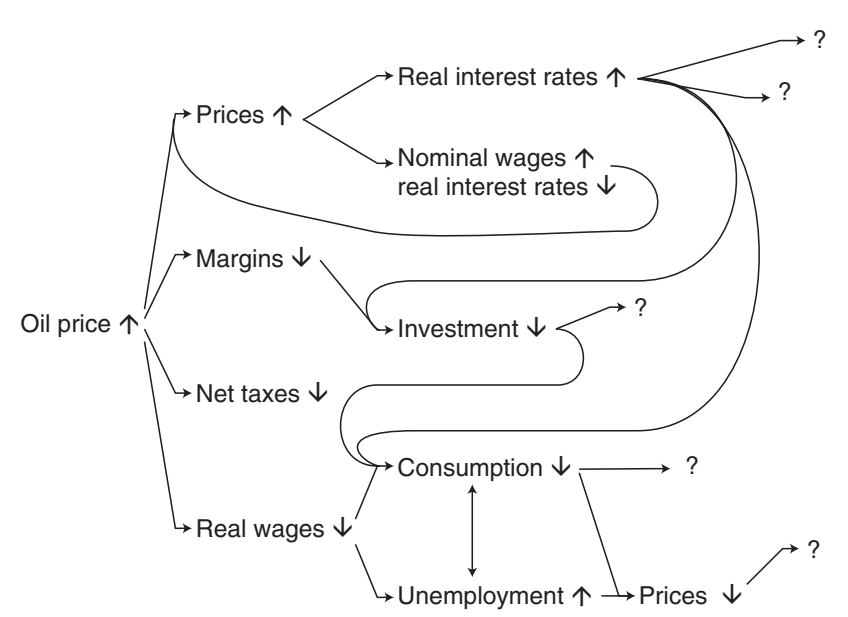

Figure 1

Propagation of an oil price increase: Decisions and their implications.

\subsection{Oil Price Variations vs. "Oil Shock"}

Empirical research on the impact of oil price movements has benefited by the work done in other areas of economic research. Two patterns have specifically aroused strong interest.

According to the "dispersion hypothesis" [6], an exogenous shock can cause inter- and intra-sectoral imbalances (between demand and supply of production factors) which can lead to a durable under-utilization of labour and capital resources in certain industries. With respect to employment, in particular, the rise in unemployment would be greater and longer if the agents wrongly expected that the impact of the shock would be short-lived, and if switching from one branch of activity to another incurs a cost.

According to the hypothesis of deferred investment in the presence of uncertainty, the value associated with the option of postponing an investment decision sharply increases when the useful information concerning the future trend in prices of an input is awaited [7,8]. Consequently, if the agents have this choice, they will tend to defer their investment decisions in "putty-clay"1 technologies until the information is known.

Rigidities, market imperfections and anticipations of the agents could exacerbate the direct impact of price variations, and make way for indirect influences associated with the absolute value of the variations.

Thus, a downward drop in the price of oil could, if it causes sectoral imbalances or greater uncertainty, exert a detrimental "indirect" influence that would offset the favourable "direct" effects. If prices rise, the effects would be magnified. Market imperfections, particularly employment

1 A "putty-clay" production technology displays broad possibilities of substitution before being implemented, but limited possibilities once installed. rigidities and imperfect information, could exert a multiplying effect on the increases and neutralize the beneficial effects of decreases.

The empirical validation of these hypotheses and the quantification of the effects is difficult at the macroeconomic level, because of the need to construct a measurement of the "oil shock" expressing the aggregate, asymmetric and nonlinear influence of price movements. The measurements proposed reflect a wide variety of opinions, such as there are "not any significant effects of oil price declines" [4], "it seems more appropriate to compare the current price of oil with where it has been over the previous year rather than during the previous quarter alone" [9] (Figs. 6 and 7), or "an oil shock is likely to have greater impact in an environment where oil prices have been stable than in an environment where oil price movement has been frequent and erratic" [10] (Fig. 5). Generally speaking, empirical analyses exploiting "oil shock" measurements display two weaknesses that limit their practical value: from the theoretical standpoint, the measurements used are not justified except by an opinion as expressed in the quotations above $[11,12]$; empirically, the equations estimated using these measurements generally prove to be unstable and non-significant after a few years $[13,14]$.

Estimates of equations between the price of oil and economic indicators depend heavily on the effects taken into account in the model and the empirical approach used to construct it. The differences between the elasticities obtained reflect the differences between the assumptions introduced into the models, and particularly in the transformation applied to the price of oil.

The IMF (International Monetary Fund, [15]), FRB (Federal Reserve Board) and OECD [16] models treat oil price variations as any shocks on supply and obtain elasticities close to $-1 \%$ for the United States (when monetary policy is not expansionist). Using the OECD model, the IEA [2] estimated that a \$25 to \$35 increase in the barrel price causes a two-year drop in GDP of 0.3 percentage points in the United States, 0.4 points in Japan and 0.5 points in the Euro zone countries considered as a whole.

Most of the other researches and empirical studies conducted on the subject use American data. For example, Mory [17] and Mork et al. [18] obtained estimates of GDP elasticity to price increases of $-5.5 \%$ and $-5.4 \%$ respectively from autoregressive, log-linear regressions of GDP. With the "oil shock" measurements of Hamilton ([3]; Fig. 7) and of Lee, Ni and Ratti ([10]; Fig. 5), the results obtained are $-11.62 \%$ and $-5.35 \%$ respectively (after 8 quarters). Dotsey and Reid [19] obtained a cumulative elasticity of $-9.4 \%$ at the time that the reaction is strongest (after 7 quarters) for a specification using the Federal Fund rate.

Jones, Leiby and Paik [20] report that the US Department of Energy (DOE), in its analyses of energy policy, used a value of between $-2.5 \%$ and $-5.5 \%$ over the last 15 years. 
As to the other countries, and particularly the European countries, far fewer studies have been produced. Worth mentioning are Mork et al. [18] and Papapetrou [21]. The former obtained estimates of GDP elasticity to price increases of $-2.3 \%$ for Japan, $-8.1 \%$ for West Germany, $-9.8 \%$ for France, $-6.4 \%$ for Canada, $-3.8 \%$ for the United Kingdom and $5.1 \%$ for Norway. As to Papapetrou, she analyzes the impact of the consumer price index of petroleum products on the Greek economy between 1981MI and 1999M6, and estimates for industrial production and employment elasticities of $-2.7 \%$ and $-0.8 \%$ respectively.

More recently, Jimenez-Rodriguez and Sanchez [22] compared the elasticities estimated (for a $100 \%$ increase in the leading industrialized countries) using a conventional measurement of the price of oil with those obtained using an "oil shock" measurement: in the former case, the GDP losses are $3.5 \%$ in the United States and about $2 \%$ for the European countries (including the United Kingdom, an exporter), while the GDP gains of Norway are 1\%; in the latter case, the GDP losses are up to $5 \%$ in the United States, ranging from 3 to $5 \%$ for the European countries $(2.28 \%$ in the United Kingdom) and the gains of Norway amount to $2.6 \%$.

\subsection{Disaggregate Analyses and Microeconomic Effects}

As to disaggregate analyses, they supply results that are more interesting but are generally not easy to summarize.

Some economists have analyzed the influence of oil price on the American economy using regional [23] or sectoral data [24-27]. The extreme complexity of these analyses makes it difficult to synthesize their results. In particular, the aggregate impact (on GDP or employment at the national level) of a change in the price of oil depends on the shares of the various regions or the various sectors in the economy, and therefore evolves over time.

In the short term, the price shift, more or less abrupt, vitiates the allocation of production factors (capital and labor), and can also cause a disequilibrium between worker skills and capital characteristics on the one hand, and company needs on the other. Thus, the American automotive industry ran on undercapacity for several years after the first oil shock [28] because demand for large vehicles, the models in which the automakers were specialized, fell in favor of compact, less fuel-greedy cars, for which they had neither the technical skills nor the associated commercial skills, particularly aesthetic expertise. The Japanese automotive industry largely exploited this switch in demand by gaining market share.

On average, Davis and Haltiwanger [25] estimate that a positive shock of one standard deviation on the price of oil leads to the destruction of 290000 jobs and the creation of 30000 jobs in the first two years following the price hike (for comparison, the 1973-74 shock corresponded to a shock of
1.7 standard deviations and the $1979-81$ shock to 2 standard deviations). After four years, the net response consists of the disappearance of 60000 jobs and the reassignment of 414000 workers, representing more than $3 \%$ of the total industry payroll. Besides, the impact of an oil shock is more pronounced for companies with a high capital to labor ratio, which produce durable goods and which have strong needs for energy in their production systems (these criteria are classed by order of importance).

Moreover, costlier oil has an unequal impact on skilled and other workers [24]: in the short term, the former suffer a smaller drop in their real wages; in the long term, the likelihood of finding themselves out of a job is lesser.

In the conditions of 1996 for the economic structure (according to the SIC classification into 10 super-sectors), the sectoral energy intensities and the value shares of imports in the GDP and of petroleum products in imports, Lescaroux estimates a short term elasticity of $-3.1 \%$ between real US GDP and the production price index for petroleum products.

\subsection{Sources of Temporal Instability}

Apart from the reduced energy intensity of the industrialized countries in the last 30 years, many sources of variability can be found in the relationship between the oil price and economic activity. A higher cost per barrel does not propagate in a predetermined way through the economic system, and the choices of the various agents (individuals, companies, governments and, above all, the monetary authorities) condition development. These choices are obviously strongly influenced by the current situation and by anticipations to various time horizons.

As to the second of these decision making determinants, a learning mechanism has been active in the field of monetary policy. In the long term, the Central Banks no longer rely on the arbitrage between inflation and unemployment expressed by the first version of the "Phillips Curve". The consideration of adaptative expectations has led to long range rectification of the curve.

In the early 1980s, during the term of Paul Volcker, controlling inflation became the Fed's top priority. This reversal in the ranking of objectives meant that the monetary authority would react far more drastically to rising price indexes (in a "Taylor Rule" type of equation, this development was reflected by an increase in the $g_{p}$ factor, $c f$. inset: the "Taylor Rule") and it led to a durable rise in base lending rates.

Since then, there is a correlation between oil "shocks" and monetary "shocks". According to Bernanke, Gertler and Watson [12], the major share of GDP losses following rising crude prices was due to the restrictive policies adopted by the Fed to fight inflation, and particularly to the increases in the Federal Fund Rate, tending to suggest that the new governor of the Federal Reserve Bank, Ben Bernanke, is unlikely to 
react too vigorously to increasing crude oil prices, as long as inflationary risks are under control.

\section{The "Taylor Rule"}

Roughly speaking, the behavior of the Federal Fund Rate set by the Federal Reserve Bank can be modelled by a Taylor Rule [29]:

$$
i_{t}=g_{\pi} \cdot \pi_{t}+g_{y} \cdot y_{t}+g_{0}
$$

where $i_{t}$ is the nominal short term interest rate, $p_{t}$ is the inflation rate and $y_{t}$ is the deviation, in percentage, of the real GDP from its potential. The coefficient $g_{y}$ (negative) determines the response of the Federal Reserve Bank to the change in GDP and $g_{y}$ (positive) and $g_{0}$ (negative) determine the "target" set by the monetary authority pertaining to the inflation rate and its response to the differences observed. This formulation expresses the arbitrage of the Federal Reserve Bank between its two objectives: stabilize prices and promote growth.

Due to this greater vigilance of the Central Banks concerning price movements, it now appears certain that the increases in prices of petroleum products are no longer passed on to the core inflation [30]. In particular, inflationary spirals (rising prices/rising wages) like those associated with the first oil shock, need no longer be feared.

In these conditions, however, the empirical analysis of the impact of oil price variations is complicated by the changing practices in the monetary area.

Whether too accommodating or too restrictive, monetary policy is undoubtedly an art of fine tuning, where neutrality is difficult to define objectively.

A final current of monetarist inspiration also considers that the stagflation episodes following the first two oils shocks resulted from the too erratic measures adopted by the Federal Reserve Banks and the "stop and go" policies implemented [31].

Monetary policy decisions, and economic decisions in general, also depend on the present context. Raymond and Rich [32] specifically analyzed the impact of the oil price on the American economy according to the phase of the economic cycle during which the price variation occurred. They concluded that a rise is detrimental when it occurs in a period of weak growth or recession, but has no impact in periods of strong growth.

This statistical result can be explained by the changing power relationships between the groups of economic agents during the economic cycle, and by the existence of broader leeway when economic activity accelerates than when it slows down.

The first two oil shocks occurred during deceleration phases of economic activity. In contrast, the present rise is accompanied by a period of acceleration.
The phase of the economic cycle influences value added sharing. It appears that companies today do not enjoy sufficient market power to raise their selling prices because of the pressure of international competition which deters them from passing on the increases in production cost to their consumers.

For the time being, therefore, costlier oil is primarily reflected in company unit profits.

\section{WHAT CAN WE EXPECT FROM THE RECENT RISE IN THE PRICE OF OIL?}

As pointed out by Alfred Marshall [33], «the complex problem of value must be broken up» (V.V.2): it is important to distinguish between the impact of an upward disequilibrium and an upturn in the equilibrium. In this regard, most of the analyses mentioned could turn out to be of limited use in the present situation.

Loosely speaking, the principle of spectral analysis is to express a times series $y_{t}$ as a weighted sum of periodic functions of the form $\cos (w . t)$ and $\sin (w . t)$. From this formulation, one can derive the sample periodogram of the series, which plots on the $y$-axis a measurement of the portion of the sample variance of $y_{t}$ that can be attributed to cycles of frequency $f_{i}$ (or periodicity $T_{i}=1 / f_{i}$ ) against the frequency $f_{i}$ (or the periodicity $T_{i}$ ) on the $x$-axis (for more on the issue of signal processing, see [34]). Then, one can decompose the times series into a long-run component and a short-run component by using the sample periodogram to identify the most appropriate limit between short- and long-run evolutions ${ }^{2}$ and by applying spectral filters.

2 "Of course, there is no hard and sharp line of division between "long" and "short" periods" (Marshall, 1890, V.V.8). As pointed out by Marshall, this distinction is an artificial but convenient tool.

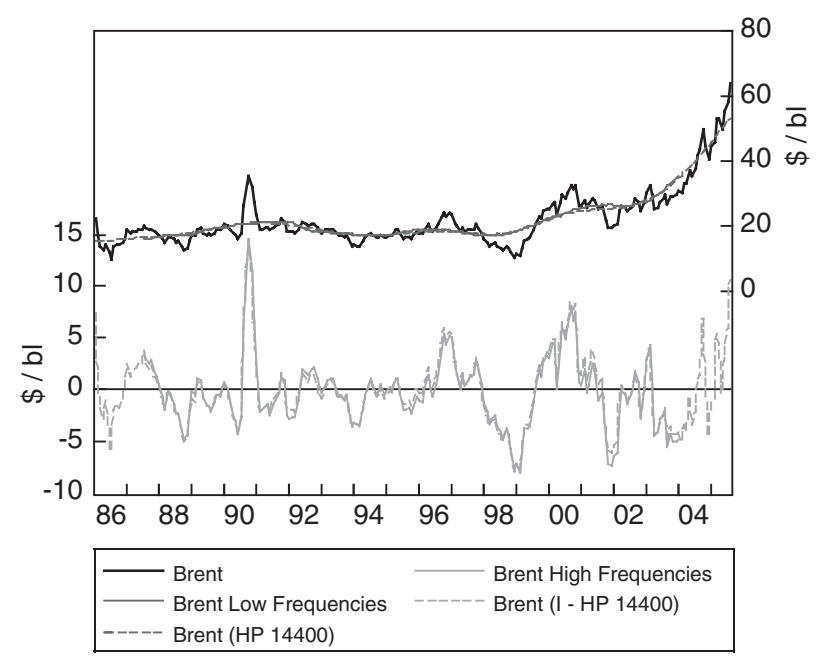

Figure 2

Brent spot price and its high and low frequency components. 


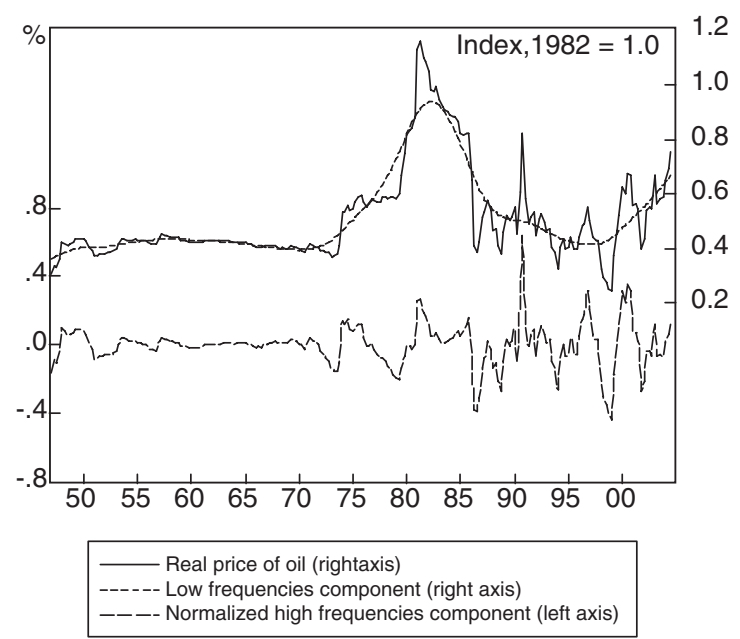

Figure 3

Real price of oil and its spectral high and low frequency components.

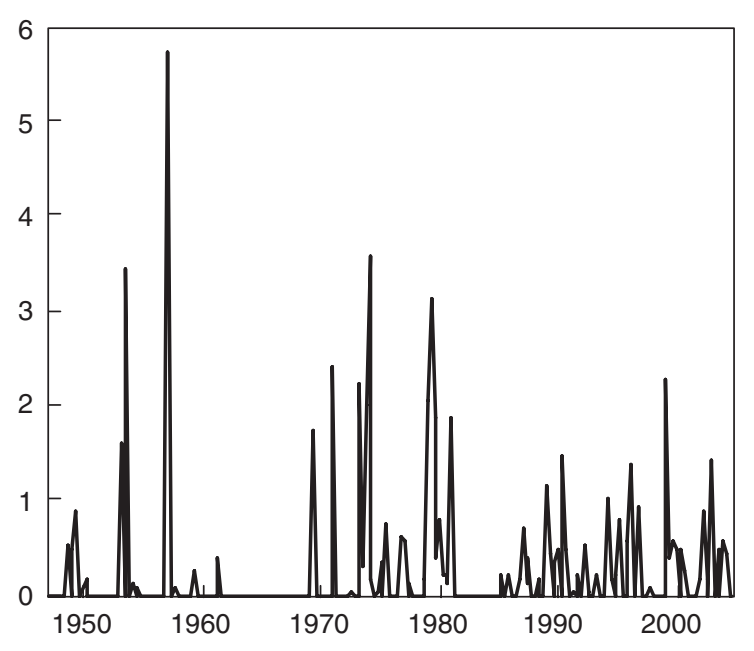

Figure 5

"Oil shock" variable of Lee et al. (1995)

As shown in Figure 2, we are in fact faced with a rise in the equilibrium price of oil (in the spirit of Marshall, the "normal values" are considered as "the centres about which the amount and the price tend to oscillate", that is there are assimilated to the low frequency component of the series ${ }^{3}$ ). The published results are generally obtained using models that do not differentiate between the variations in the high frequency component and those in the low frequency component, and in which the greatest confusion appears to surround this distinction.

3 The low frequency component of crude expresses its long run variations. In Figure 2, it has been extracted with a "window" low-pass filter. This kind of filter consumes data at the extremities of the sample; therefore, we also approximated it with a Hodrick-Prescott filter with a parameter of 14400 .

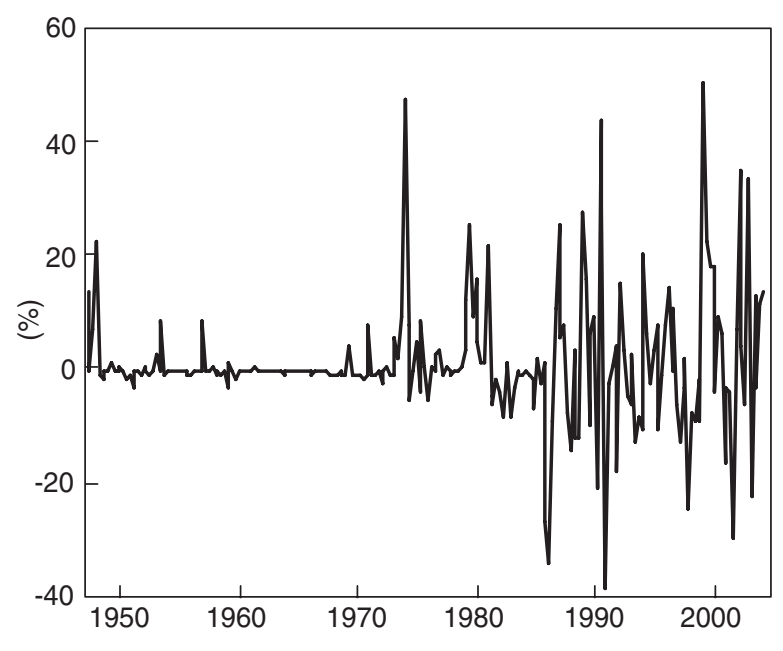

Figure 4

Rate of variation of the price.

\subsection{The Contrasted Effects of Cycles and Breaks in the Price of Oil}

The extent of the range of estimated elasticities is partly explained by the fact that the analyses address distinct problems.

The "standard" effects identified are clearly exerted in the short term in case of an upward rise in prices.

On the other hand the appearance of inter- and intrasectoral imbalances or the deferral of investment decisions can only result from a durable price increase like the one observed today.

For the sake of simplification, we can therefore consider that the analyses that use price variations as a petroleum variable (Figs. 3 and 4), quantify the "standard" effects associated with the fluctuations in crude prices about its equilibrium level, while those based on "oil shock" measurements (Figs. 3 and 5 to 7) try to evaluate the consequences of a break in the equilibrium level.

This is not, strictly speaking, true because the former do not completely eliminate the low frequency component of the time signal representing the price of oil by considering it as a range of variation and, above all, the latter do not perfectly neutralize the high frequency component with the filters they apply in order to construct their "oil shock" measurements (particularly [9, 10]).

\subsection{Quantifying the Impact of Cycles and Breaks in the Oil Price}

Accepting this reservation, the elasticities of real American GDP with respect to an upward imbalance and with respect to a rise in the equilibrium price would accordingly lie 


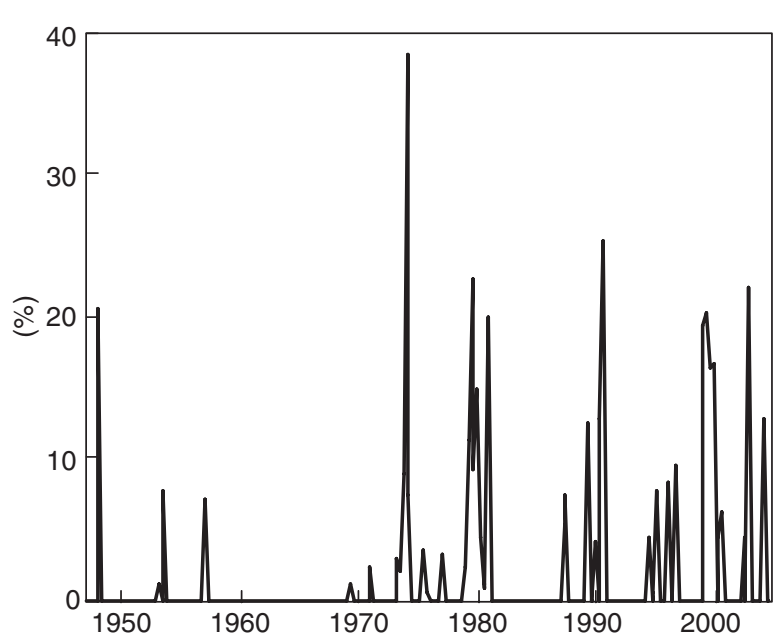

Figure 6

“Oil shock" variable of Hamilton (1996).

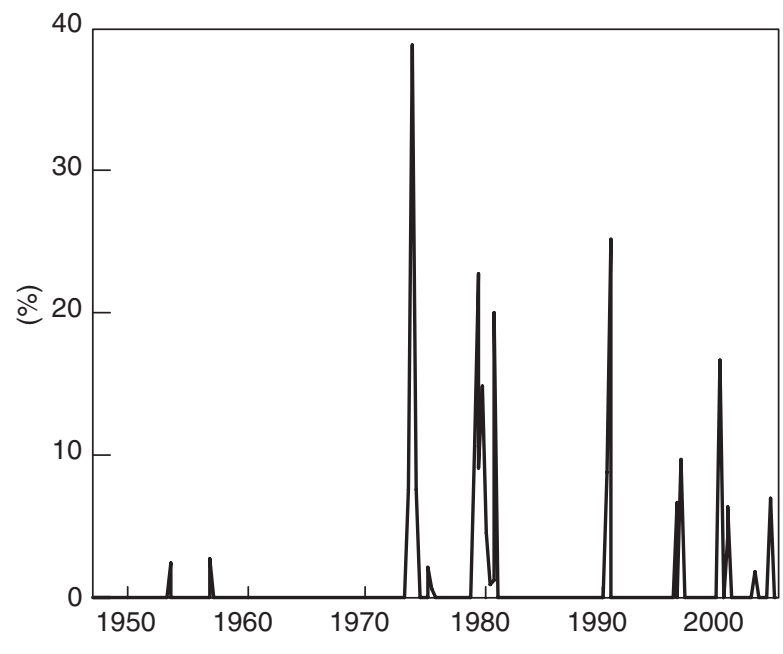

Figure 7

"Oil shock" variable of Hamilton (2003). approximately in the ranges extending, respectively, from $-1 \%$ to $-5.5 \%$ and from $-5 \%$ to $-11.5 \%$.

The interval in the former case reflects the variability of the impact of an oil price fluctuation according to its shape and to a set of short- and long-run parameters. Lescaroux [27] explicitly models the relationships between the high frequency components of the economic variables and the high frequency component of the petroleum product price index. The elasticity of real American GDP and the oil price is especially higher when the imbalance is longer and sharper, and increases very slowly in absolute value, with the maximum amplitude. The elasticity of $-3.1 \%$ mentioned earlier corresponds to the reaction, in the 1996 situation, of the real GDP to a rectangular imbalance lasting six quarters and with an amplitude of $10 \%$. For a period of one quarter (respectively 8 quarters), the elasticity becomes lower (resp. higher) in absolute value, than $-1 \%$ (resp. $-3.5 \%$ ). These elasticities are obtained by imposing an oil price variation to the economic system considered at its long-run steady-state equilibrium; they therefore correspond to a mean response. The recessionary impact is deeper (resp., less deep) when the price rise occurs in a decelerating (resp., accelerating) phase of the business cycle. The relationships are stronger when the model is simulated in the structural conditions of 1973, in terms of the relative shares of the industrial sectors, the share of importations in GDP and the share of petroleum products in total importations.

So, the fluctuations in the oil prices have a moderate impact on economic activity with a decreasing trend, despite some variability.

The consequences of a change in regime (that is, a period of relative stability in the long-run equilibrium level of oil prices) like the one observed today are more difficult to analyze. The problem of interest in the current situation is to evaluate the impact of a structural break in the price of oil. But the range of estimated elasticities provided by studies using "oil price shock" measures must be regarded with extreme caution.

As we have already pointed out, the numerical values of the elasticities obtained depend heavily on the choice of the oil shock measurement used, whereas the main functional forms proposed are not theoretically justified and empirically lead to regressions which turn out to be unsatisfactory only a few years after their publication. This search for an ad hoc filter that would help to reveal a stable and significant relationship between the oil price and the GDP or the unemployment rate, has been compared to data mining by Bernanke, Gertler and Watson [12].

Generally speaking, we can question the relevance of an econometric approach when quantifying the consequences of exceptional events. In fact, the breaks in the record of the price of oil are relatively rare and have, so far, coincided with shocks of other natures (end of the Bretton Woods monetary system in the early 1970s, tightening of American monetary policy and rise of the dollar in the early 1980s). It is therefore difficult to distinguish statistically between the respective consequences of these various influences. Moreover, due to their violence, these events encourage a vast number of researches and analyses aimed at a closer understanding and better identification of the least appropriate decisions, in order the avoid the mistakes of the past. Thus for example, the greater vigilance of the Federal Reserve Banks with respect to inflation will no doubt help in the future to avoid price/wage spirals. Similarly, the price control policies implemented in most of the western countries in the early $1970 \mathrm{~s}$ revealed their ineffectiveness and their dangers. Thus the oil shocks appear to be not enough frequent and their consequences appear to be too variable to lend themselves satisfactorily to econometric analysis. 
Without even going as far as the use of a statistical model to predict the consequences of costlier oil, it could be a mistake to refer to the experiences of the 1970s and 1980s. In fact, shifts in the equilibrium level of the price of oil bring structural adjustments of the economic system and of society as a whole in their wake.

After the first two oil shocks, the rise in prices encouraged users to control their consumption and to optimize it to enable marginal energy products to adjust to their prices. This was achieved thanks to efficiency gains in plant and equipment. Often, the industrial structure also refocused on sectors offering the lowest energy intensities. And energy consumption became more efficient, with the allocation of the various forms of energy to the uses for which they offer the best yields: the energy mix diversified and, for instance, oil is more and more consumed in the transport sector.

Moreover, the globalization and the accelerated development of some countries has induced changes in the international trade in goods and services. Oil revenues have predominantly benefited to western countries after the first two oil shocks; the share of emerging countries is actually close to $50 \%$ in the total imports of the principal oil exporting countries [15]. The I.M.F. also note that these revenues are, till now, recycled less rapidly than during the 70s and 80s. However the growing perception of a rise in the long-run equilibrium level of oil prices might soon lead to an acceleration in consumption expenditures of many important exporters who face a rise of their needs resulting from the strong demographic pressure.

\section{CONCLUSION}

Despite some variability, the influence of short-run fluctuations in the oil price is well known and the elasticity between real GDP and them lie in the range going from $-1 \%$ to $-5.5 \%$.

But concerning the effects of a change in regime, the estimated elasticities are not reliable and the analysis of the past can just shed a little light on the forthcoming evolutions for two reasons: the structural conditions of the rise are not the same and the efforts made to adapt can be continued but not repeated.

One of the chief factors of uncertainty associated with the current rise in oil prices concerns the forthcoming demand pattern in the developing countries. During the first two oil shocks, the increase in consumption essentially occurred in the OECD countries, and after the fleeting attempts to establish price controls, the rise in consumer prices allowed a selfcorrective mechanism to act by a levelling off in demand. In recent years, incremental demand comes mainly from the emerging countries, where energy price policies are governed by social rather than economic considerations. Olivier Rech [35] drew attention to the multiplication by a factor of two to five of the cost associated with the fuel subsidy systems in a group of big oil consuming countries, like China, India, Indonesia, Thailand and Egypt. Despite the impact on the standard of living of their population and the attendant political risks, the governments of these countries cannot allow their public finances to deteriorate indefinitely. At their rates, they will have to let consumer prices rise. Here and there, we are starting to observe such developments (in Thailand for example) as well as their early effects on demand for petroleum products.

\section{REFERENCES}

1 McKillop A. (2004) A counterintuitive notion: economic growth bolstered by high oil prices, strong oil demand, Oil \& Gas J., Apr. 19, 18-24.

2 Analysis of the impact of high oil prices on the global economy. Energy prices and taxes, International Energy Agency (2nd trimester 2004).

3 Hamilton J.D. (2003) What is an oil shock? J. Econom. 113, 363-398.

4 Mork K.A. (1989) Oil and the macroeconomy when prices go up and down: An extension of Hamilton's results, J. Political Econ. 97, 3, 740-744.

5 Hooker M. (1996) What happened to the oil price-macroeconomy relationship? J. Monetary Econom. 38, 195-213.

6 Lilien D.M. (1982) Sectoral shifts and cyclical unemployment, J. Political Econ. 90, 4, 777-793.

7 Bernanke B.S. (1983) Irreversibility, uncertainty, and cyclical investment, Q. J.Econom. 98, 1, 85-106.

8 Pindyck R.S. (1991) Irreversibility, uncertainty and investment, J. Econom. Literat. 29, 3, 1110-1148.

9 Hamilton J.D. (1996) This is what happened to the oil pricemacroeconomy relationship, J. Monetary Econom. 38, 215-220.

10 Lee K., Ni S., Ratti R.A. (1995) Oil shocks and the macroeconomy: The role of price variability, Energy J. 16, 4, 39-56.

11 Hooker M. (1996) This is what happened to the oil pricemacroeconomy relationship: Reply, J. Monetary Econom. 38, 221-222.

12 Bernanke B.S., Gertler M., Watson M. (1997) Systematic monetary policy and the effects of oil price shocks, Brookings Papers on Econom. Activity 1, 91-142.

13 Hooker M. (1997) Exploring the robustness of the oil pricemacroeconomy relationship, Federal Reserve Board (FEDS), Working Paper 1997-56.

14 Hooker M. (1999) Oil and the macroeconomy revisited, Federal Reserve Board (FEDS), Working Paper 1999-43.

15 Oil Prices and global imbalances, World Economic Outlook, International Monetary Fund (april 2006).

16 Organisation of Economic Co-operation and Development (2004) Évolution des prix du pétrole : moteurs, conséquences économiques et ajustement des politiques, Perspectives Économiques de l'O.C.D.E. 76, 147-170.

17 Mory J.F. (1993) Oil prices and economic activity: Is the relationship symmetric? Energy J. 14, 4, 151-161.

18 Mork K.A., Olsen Ø., Mysen H.T. (1994) Macroeconomic responses to oil price increases and decreases in seven OECD countries, Energy J. 15, 4, 19-35. 
19 Dotsey M., Reid M. (1992) Oil shocks, monetary policy, and economic activity, Federal Reserve Bank of Richmond Economic Rev. 78, 4, 14-27.

20 Jones D.W., Leiby P.N., Paik I.K. (2004) Oil price shocks and the macroeconomy: What has been learned since 1996, Energy J. 25, 2, 1-32.

21 Papapetrou E. (2001) Oil price shocks, stock market, economic activity and employment in Greece, Energy Econom. 23, 511532 .

22 Jimenez-Rodriguez R., Sanchez M. (2004) Oil price shocks and real GDP growth - Empirical evidence for some OECD countries, ECB Working Paper Series, No. 362.

23 Davis S.J., Loungani P., Mahidhara R. (1997) Regional labor fluctuations: oil shocks, military spending, and other driving forces, Board of Governors of the Federal Reserve System, International Finance Discussion Paper, No. 578.

24 Keane M.P., Prasad E.S. (1996) The employment and wage effects of oil price changes: A sectoral analysis, Rev. Econom. Stat. 78, 389-399.

25 Davis S.J., Haltiwanger J. (2001) Sectoral job creation and destruction responses to oil price changes, J. Monetary Econom. 48, 465-512.

26 Lee K., Ni S. (2002) On the dynamic effects of oil price shocks: A study using industry level data, J. Monetary Econom. 49, 4, 823-852.
27 Lescaroux F. (2006) Le prix du pétrole et les cycles conjoncturels américains. PhD Thesis, ENSPM/UB.

28 Bresnahan T.F., Ramey V.A. (1993) Segment shifts and capacity utilization in the U.S. automobile industry, Am. Econom. Rev. Papers Proc. 83, 2, 213-218.

29 Taylor J.B. (1998) An historical analysis of monetary policy rules, NBER Working Paper 6768.

30 Hooker M. (1999) Are oil shocks inflationary? Asymmetric and nonlinear specifications versus changes in regime, Federal Reserve Board (FEDS), Working Paper 1999-65.

31 Barsky R.B., Kilian L. (2002) Do we really know that oil caused the great stagflation? A monetary alternative, in NBER Macroeconomics Annual 2001, Bernanke and Rogoff (eds.).

32 Raymond J.E., Rich R.W. (1997) Oil and the macroeconomy: A Markov state-switching approach, J. Money Credit Banking 29, 2, 193-213.

33 Marshall A. (1920) Principles of Economics, Londres: McMillan et Cie, Ltd, 8th edition (first edition: 1890).

34 Blanchet G., Charbit M. (2006) Digital signal and image processing using MATLAB, ISTE London-Newport Beach.

35 Rech O. (2006) L'offre et la demande pétrolière, Panorama 2006 - IFP, janvier 2006.

Final manuscript received in July 2007

Copyright () 2007 Institut français du pétrole

Permission to make digital or hard copies of part or all of this work for personal or classroom use is granted without fee provided that copies are not made or distributed for profit or commercial advantage and that copies bear this notice and the full citation on the first page. Copyrights for components of this work owned by others than IFP must be honored. Abstracting with credit is permitted. To copy otherwise, to republish, to post on servers, or to redistribute to lists, requires prior specific permission and/or a fee: Request permission from Documentation, Institut français du pétrole, fax. +33147527078 , or revueogst@ifp.fr. 